\title{
Axillary Tail of the Breast
}

National Cancer Institute

\section{Source}

National Cancer Institute. Axillary Tail of the Breast. NCI Thesaurus. Code C12305.

The superolateral extension of the mammary gland into the axilla that consists of fibroadipose tissue, lymph nodes, and lymphatics. 